\title{
Trabalho abstrato, subjetividade e alienação em Marx: notas para uma "fenomenologia da vida alienada" a partir de 0 capital
}

Vinícius Santos ${ }^{1}$

\section{Resumo:}

O artigo busca relacionar a noção de "trabalho abstrato", tal como aparece em O capital, ao conceito de alienação, presente em diversos textos de Marx. O intuito é traçar um horizonte teórico a partir do qual será possível analisar o impacto dos processos de abstração que sustentam a sociedade burguesa na formação da subjetividade no presente. Nesse sentido, este trabalho serve de passo inicial para a constituição de uma descrição fenomenológica da vida alienada na contemporaneidade neoliberal.

Palavras-chave: Alienação; subjetividade; neoliberalismo; trabalho abstrato.

\section{Abstract labor, subjectivity and alienation on Marx - notes for a "phenomenology of the alienated life" from Capital}

\begin{abstract}
:
The paper intends to connect the notion of "abstract labor", as it appears in Capital, with the concept of alienation, present in several Marx texts. The aim is to draw a theoretical horizon from which it will be possible to analyze the impact of the processes of abstraction that sustain bourgeois society in the formation of subjectivity in the present. In this sense, this article serves as an initial step towards the constitution of a phenomenological description of the alienated life in neoliberal contemporaneity.
\end{abstract}

Key words: Abstract labor; alienation; neoliberalism; subjectivity.

1 Doutor, professor da Universidade Federal da Bahia (UFBA). E-mail: vsantos1985@gmail.com. 
Em carta a Engels, datada de 24 de agosto de 1867, Marx assinala que a maior contribuição de O capital, "fundamental para a compreensão de todos os fatos" ali analisados, foi ter revelado o "duplo caráter do trabalho, seja ele expresso em forma de valor de uso ou valor de troca" (MARX; ENGELS, 2010, p. 407, tradução nossa).

Não é difícil compreender a centralidade conferida pelo autor a esse tema: afinal, é o duplo caráter do trabalho, ou, mais precisamente, a constatação da posição (no sentido dialético que vem desde Fichte setzen) social desta abstração (FAUSTO, 2015, pp. 127 ss), que sustenta sua teoria do valor, cerne da crítica da economia política. Neste trabalho, porém, mais do que acompanhar os meandros dessa crítica, o que interessa é compreender como o referido processo de abstração operado pela produção burguesa não se limita ao plano econômico, mas, antes, é contemporâneo ao domínio que a filosofia clássica costuma definir por subjetividade. Mais precisamente, trata-se de vincular a noção elementar de abstração, que qualifica o trabalho produtor de valor privilegiado pela sociedade burguesa no âmbito da "reprodução simples", ao que, a nosso ver $^{2}$, é o núcleo do sistema de pensamento marxiano e fornece a tônica do entendimento da totalidade da sociedade burguesa: a noção de alienação ou estranhamento [Entfremdung], anverso - no nível da "reprodução ampliada"3 - daquela abstração. Nesse sentido, cumpre esclarecer: o que se pretende alinhar na sequência é o primeiro movimento de uma pesquisa voltada para a posterior constituição daquilo que, no subtítulo deste trabalho, é anunciado como uma "fenomenologia4 da vida alienada". Bem entendido, o que visamos futuramente, com este texto enquanto indicativo

2Em consonância com o que defende István Mészáros, por exemplo, para quem a alienação é o "núcleo" e a "ideia básica do sistema marxiano" (MÉSZÁROS, 2010, p. 91).

${ }^{3}$ Nossa posição se justifica pelo entendimento de que, à medida que a produção mercantil avança, o capital não pode apenas se reproduzir pelo processo de compra e venda da força de trabalho. Sua perpetuação exige doravante a completa dominação do processo em relação aos homens, isto é, sua inteira submissão a uma lei fundamental (a lei da acumulação de capital) que aparece "mistificada em lei da Natureza" (MARX, 1996, p. 253). Isso significa que o próprio desenvolvimento do capitalismo converte intrinsecamente o processo de reprodução simples do capital (essencialmente econômico) em um processo que se expande para a totalidade da vida social - aí inclusas a própria compreensão de si do indivíduo, sua "consciência" e sua práxis. A reprodução capitalista torna-se reprodução ampliada, e a lógica da alienação - que, como tentaremos mostrar, perfaz o anverso dos processos de abstração pelos quais o capital se reproduz - se universaliza para todos os outros níveis (político, cultural, religioso, psíquico, intersubjetivo etc.). Com isso, deixa de haver uma mera subsunção formal do trabalhador ao sistema (as condições de extração da mais-valia absoluta, juridicamente asseguradas pelo contrato de trabalho e assentadas naquela separação absoluta entre os trabalhadores, os meios e produtos do trabalho), cedendo passo a uma subsunção real dos indivíduos a este processo, base do processo de extração da mais-valia relativa (cf. MARX, 2004a, pp. 87-108).

4 A noção de fenomenologia aqui tem o viés dialético, de inspiração hegeliana: descrição de "figuras" nas quais a alienação, tal como entendida na sequência, se manifesta contemporaneamente. 
teórico preliminar, é a delinear "figuras" pelas quais a experiência vivida da alienação se manifesta na experiência cotidiana presente, em diversos níveis, tendo como pano de fundo privilegiado, mas não exclusivo, a teoria crítica marxiana. Para tanto, devemos desde já apontar em que medida a hipótese teórica de Marx ainda pode se mostrar fecunda para a abordagem de problemas contemporâneos concernentes à subjetividade - problemas, em última instância, advindos das transformações do modo de produção capitalista nas últimas décadas - , em especial, o modo patológico pelo qual essas transformações podem ser experimentadas concreta ou “existencialmente" pelos indivíduos 5 .

Inicialmente, importa definir aquilo que Marx entende por abstração no âmbito de sua descrição do trabalho abstrato. A célebre argumentação com a qual se inicia $\mathrm{O}$ capital toma como ponto de partida a mercadoria desde sua dupla natureza: enquanto meio de satisfação de alguma carência humana (independentemente de sua origem) e enquanto objeto de intercâmbio, isto é, como valor de uso e valor de troca (cf. MARX, 1988, pp. 45-9) ${ }^{6}$. Do primeiro ponto de vista, como se sabe, as mercadorias são completamente heterogêneas, distintas umas das outras, já que se distinguem em suas qualidades físicas constitutivas e, por conseguinte, também na utilidade para seus proprietários. Quando adentra o mercado como valor de troca, ou simplesmente valor, no entanto, toda mercadoria aparece como equivalente potencial de todas as outras. Para isso, é preciso que todas tenham algo em comum. Este algo em comum, entretanto,

não pode ser uma propriedade geométrica, física, química ou qualquer outra propriedade natural das mercadorias. Suas propriedades corpóreas só entram em consideração à medida que elas lhes conferem utilidade, isto é, tornam-nas valor de

\footnotetext{
5 Do ponto de vista marxista, é imprescindível, desde já, que se faça uma ressalva em nossa proposta. Neste texto, vamos nos referir, sobretudo, a indivíduos, de modo genérico, e não a classes sociais. Trata-se, evidentemente, de uma abstração. Ocorre que, aqui, limitamo-nos a demarcar um horizonte conceitual que permita pensar as bases em que a alienação atinge o conjunto da sociedade burguesa enquanto núcleo do processo de abstração real que sustenta a reprodução capitalista. Em outra oportunidade, será necessário indicar o modo pelo qual a cisão social de classes medeia as formas pelas quais esses processos de abstração e, ato contínuo, de alienação ressoam nos indivíduos. Ademais, igualmente oportuno será considerar, desde essa perspectiva classista, também a incidência das mediações de gênero e raça na conformação da subjetividade tipicamente alienada de nossa era.

6 Por mera questão de familiaridade, optamos aqui por utilizar a consagrada tradução de O capital feita por Regis Barbosa e Flávio Kothe presente na coleção Os economistas. Contudo, cumpre indicar a existência de uma nova tradução dos três volumes de $\mathrm{O}$ capital, competentemente realizada por Rubens Enderle, para a Editora Boitempo.
} 
uso. Por outro lado, porém, é precisamente a abstração de seus valores de uso que caracteriza evidentemente a relação de troca das mercadorias (MARX, 1988, pp. 46-7).

Assim, para que a mercadoria possa adentrar o mercado - logo, para que a sociedade burguesa possa aparecer "como uma imensa coleção de mercadorias" (MARX, 1988, p. 45) - , faz-se necessário um primeiro processo de abstração. Para que ele ocorra, é igualmente preciso que a alienação seja sustentada pela própria atividade produtora dessa abstração inicial. Portanto, este duplo caráter da mercadoria conduz Marx à tese do duplo caráter do trabalho cristalizado nessa forma específica (historicamente, embora universal na medida em que também o é o capital) que o trabalho humano assume em sociedades nas quais domina $o$ modo de produção capitalista.

Sem alongar em demasia, convém apenas ressaltar que, segundo Marx, "na própria relação de troca", o valor de troca das mercadorias aparece "como algo totalmente independente de seu valor de uso" (MARX, 1988, p. 47). Ou seja, se o "conteúdo material da riqueza" é expresso pelo valor de uso, na sociedade burguesa este é apenas o "portador" [Träger] do valor de troca (MARX, 1988, p. 46).

Por conseguinte, se o valor de uso diz respeito às distinções qualitativas das diferentes mercadorias, a autonomia do valor de troca ${ }^{7}$ deve resultar de uma distinção que só pode ser quantitativa: seu próprio valor. Mas como medi-lo? Responde Marx: "por meio do quantum nele contido da 'substância constituidora do valor'", ou seja, o trabalho humano (MARX, 1988, p. 47). É preciso acrescentar, contudo, que, à luz da utilidade das mercadorias, o trabalho empregado para produzi-las difere tanto quanto suas características qualitativas. Tantas mercadorias diversas, tantos trabalhos diversos. É o que Marx denomina trabalho concreto. Por isso mesmo, o que permite sua equivalência "substancial"8 só pode ser oriundo de um esvaziamento da concretude do trabalho. $\mathrm{Ou}$ seja, só pode surgir de um novo processo de abstração, a partir do qual o trabalho concreto humano seja reduzido a uma medida simples, e o valor, assim, seja quantitativamente estabelecido (cf. também MARX, 2004a, p. 59). Dito de outro modo, "um valor de uso ou bem possui valor, apenas, porque nele está objetivado ou materializado trabalho humano abstrato" (MARX, 1988, p. 47).

Este trabalho abstrato pode ser medido quantitativamente pelo tempo social médio necessário à produção de uma mercadoria. É este tempo que fornece o valor de qualquer exteriorização objetiva

7 Pois é disso que se trata em uma sociedade na qual a produção se volta primeiramente para a "valorização do valor", e não para a satisfação das necessidades humanas. O emprego do termo metafísioo "substância" aqui, como mostra Ruy Fausto, não é casual (cf. FAUSTO, 2015, pp. 148-53). 
[Vergegenständlichung] humana, isto é, qualquer produto do trabalho, convertido em objeto de intercâmbio mercantil.

Convém observar, entretanto, que falar em abstração sem mais considerações pode gerar um equívoco, pois a abstração visada por Marx não é uma operação mental ou uma realidade imaginária, fantasmagórica. Trata-se de uma abstração real: um processo social vivido e sustentado cotidianamente por todos os indivíduos. Lembre-se do que já aparecia, antes de $\mathrm{O}$ capital, na Contribuição à crítica da economia política:

Para medir os valores de troca das mercadorias pelo tempo de trabalho contido nelas, os diversos trabalhos devem estar reduzidos a trabalho sem diferenças, uniforme, simples; em breve, a trabalho que é qualitativamente o mesmo e, por isso, se diferencia apenas quantitativamente. Essa redução aparece como uma abstração, mas é uma abstração que é praticada diariamente no processo social de produção. A resolução de todas as mercadorias em tempo de trabalho não é uma abstração maior nem tampouco menos real que a de todos os corpos orgânicos em ar. O trabalho que é medido dessa maneira, isto é, pelo tempo, aparece não como o trabalho de diferentes sujeitos, mas, ao contrário, os indivíduos diversos que trabalham aparecem como meros órgãos do trabalho. Ou seja, o trabalho, tal como se apresenta em valores de troca, poderia expressar-se como trabalho humano geral. (MARX, 1999, p. 60)

Uma questão, porém, surge da passagem acima destacada: é que, a princípio, poderia se supor que Marx, ao falar de "trabalho humano geral", fixaria a abstração pelo viés da generalidade biológica do trabalho ${ }^{9}$. Entretanto, como esclarece Ruy Fausto, essa generalidade é inicialmente apenas pressuposta. Ela só se efetiva mediante sua posição social (em sentido dialético) enquanto supressão do caráter biológico:

Não é a realidade biológica da universalidade do trabalho que constitui o trabalho abstrato, mas a posição dessa realidade, e a posição não é mais biológica. A generalidade em sentido fisiológico (...) não constitui o trabalho abstrato: ela é apenas a realidade natural pressuposta à (posição) deste. A realidade social faz com que valha o que era apenas uma realidade natural. E que a abstração do trabalho em sentido fisiológico não pode constituir o trabalho abstrato é visível pelo fato de que lhe falta o momento da singularidade. A identidade do trabalho no nível fisiológico é a unidade dos trabalhos (fisiologicamente) idênticos. Cada trabalho considerado no nível fisiológico é idêntico ao outro, mas cada um é um trabalho (e, além disso, trabalho de alguém). Com efeito, seria impossível dizer que só

9 Nessa linha, aliás, poderia ser interpretada a seguinte passagem de O capital: "Todo trabalho é, por um lado, dispêndio de força de trabalho do homem no sentido fisiológico, e nessa qualidade de trabalho humano igual ou trabalho humano abstrato gera o valor da mercadoria." (MARX, 1988, p. 53) 
existe, lá, um trabalho, a menos que se os tome no nível da representação. Ora, essa unidade pode (e deve) ser atribuída ao trabalho abstrato. Ele é uma unidade (mesmo se, como diz Marx, esta unidade está "constituída por inúmeras forças de trabalho individuais". Aqui a pluralidade é segunda). E é precisamente esta unidade que retira aos seus agentes a condição de sujeitos [cf. parte final da citação da Contribuição acima destacada - VS] (...). É de resto esta inversão do papel dos agentes que permite compreender em que sentido (rigoroso) se diz que o trabalho abstrato é "social" e o trabalho concreto "individual", distinção que pareceria insustentável, pois o trabalho considerado trabalho concreto está também imerso no social. Mas ele é trabalho dos indivíduos, no sentido de que nesse nível os agentes não são órgãos do trabalho (tratase do trabalho concreto no nível da circulação simples). (FAUSTO, 2015, pp. 130-1)

Das passagens de Marx acima destacadas e da interpretação empreendida por Fausto, segue-se que para a abstração do trabalho ser posta socialmente - o que, ao fim e ao cabo, converte toda a riqueza capitalista em uma riqueza abstrata - é preciso que os próprios indivíduos trabalhadores sejam tomados por um processo de abstração real de si mesmos, perdendo, assim, sua condição de sujeitos. Dito de outro modo: a posição do trabalho abstrato, enquanto cerne do processo de valorização, não se dissocia da posição de uma abstração concomitante sofrida pelos seus agentes. É aqui, portanto, que o trabalho abstrato, sem se igualar, vincula-se dialeticamente à ideia de alienação. Consequentemente, é a partir desse nível que uma descrição fenomenológica da vida alienada, tal como expressamos anteriormente, deve ser empreendida. Por isso, este é o sentido de alienação que importa agora delinear. Para tanto, o auxílio de outros textos de Marx torna-se imprescindível, a começar por aquele em que o tema da alienação é pela primeira vez elaborado de forma mais exaustiva: os Manuscritos econômico-filosóficos, de 1844.

\section{II}

Conforme a leitura de Franck Fischbach, que será doravante acompanhada de perto, pode-se apreender a alienação, a partir dos Manuscritos, em seus ecos no domínio da subjetividade, em dois planos complementares: a alienação como "desobjetivação de si" e como "transferência de passividade"10. Em relação ao primeiro aspecto, é

10 Vale desde já adiantar que, em nossa perspectiva, esses dois planos em conjunto permitirão articular aquele conceito ao processo de abstração exigido pela mercantilização universal capitalista como descrito nas obras de maturidade, servindo de base para uma descrição fenomenológica da alienação manifesta na fase atual do capitalismo. 
necessário estabelecer o seguinte: segundo Marx, a história humana é o "engendramento do homem mediante o trabalho humano enquanto o vir a ser da natureza para o homem" (MARX, 2004b, p. 114). Trabalho, para o autor de $\mathrm{O}$ capital, diz respeito a todo processo de exteriorização [Entäusserung] de si do ser humano no mundo e de apropriação humana desta exteriorização tornada objetiva [Vergegenständlichung]. Assim,

quando, por um lado, para o homem em sociedade a efetividade objetiva [gegenständliche Wirklichkeit] se torna em toda a parte a efetividade das forças essenciais humanas [menschliche Wesenkräfte] enquanto efetividade humana e, por isso, efetividade de suas próprias forças essenciais, todos os objetos tornam-se [a] objetivação de si mesmo para ele, objetos que realizam e confirmam sua individualidade enquanto objetos seus, isto é, ele mesmo torna-se objeto (MARX, 2004b, p. 110).

Destarte, o trabalho inscreve os homens na natureza enquanto seres objetivos. Logo, manifesta também seu caráter de seres de necessidades, "isto é, como seres que são remetidos aos objetos como àquilo que é suscetível de satisfazer a necessidades que são naturalmente as suas" (FISCHBACH, 2009, p. 153, tradução nossa) ${ }^{11}$. Enquanto objetivação humana no mundo, portanto, o trabalho aponta para uma relação dialética entre o caráter ativo e o passivo desse mesmo ser:

O homem é imediatamente ser natural. Como ser natural, e como ser natural vivo, está, por um lado, munido de forças naturais, de forças vitais, é um ser natural ativo; estas forças existem nele como possibilidades e capacidades [Anlagen und Fähigkeiten], como pulsões; por outro, enquanto ser natural, corpóreo, sensível, objetivo, ele é um ser que sofre, dependente e limitado, assim como o animal e a planta, isto é, os objetos de suas pulsões existem fora dele, como objetos independentes dele. Mas esses objetos são objetos de seu carecimento [Bedürfnis], objetos essenciais, indispensáveis para a atuação e confirmação de suas próprias forças essenciais. Que um homem é um ser corpóreo, dotado de forças naturais, vivo, efetivo, objetivo, sensível significa que ele tem objetos efetivos, sensíveis como objeto de seu ser, de sua manifestação de vida [Lebenäusserung], ou que ele pode somente manifestar [äussern] sua vida em objetos sensíveis efetivos [wirkliche sinnliche Gegenstände]. É idêntico: ser [sein] objetivo, natural, sensível e ao mesmo tempo ter fora de si objeto, natureza, sentido, ou ser objeto mesmo, natureza, sentido para um terceiro. A fome é uma carência natural; ela necessita, por conseguinte, de uma natureza fora de si, de um objeto fora de

11 "O trabalho", acrescenta Franck Fischbach, "atividade pela qual os homens se apropriam dos objetos de suas necessidades, é, assim, igualmente a atividade pela qual eles manifestam e exprimem a objetividade de seu ser, precisamente objetivando-o exteriormente. $\mathrm{O}$ que nada mais quer dizer senão que, pelo trabalho, os seres humanos exprimem e se manifestam a si mesmos a dupla dimensão, ao mesmo tempo passiva e ativa, de seu ser." (FISCHBACH, 2009, pp. 153-4, tradução nossa) 
si, para se satisfazer, para se saciar. A fome é a carência confessada de meu corpo por um objeto existente [seienden] fora dele, indispensável à sua integração e externação essencial. Um ser que não tenha sua natureza fora de si não é nenhum ser natural, não toma parte na essência da natureza. Um ser que não tenha nenhum objeto fora de si não é nenhum ser objetivo. Um ser que não seja ele mesmo objeto para um terceiro ser não tem nenhum ser para seu objeto, isto é, não se comporta objetivamente, seu ser não é nenhum [ser] objetivo. Um ser não-objetivo é um não-ser. (MARX, 2004b, p. 127) ${ }^{12}$

Ora, é exatamente essa perda de seu ser, mais precisamente, a perda de seu objeto (entendido, vale frisar, como toda efetividade objetiva, produtos, instituições, relações sociais etc.), que exprime primeiramente o processo de alienação. Não obstante, cumpre esclarecer que, de acordo com Marx, este processo de realização ou efetivação de si dos sujeitos não é "natural". Pelo contrário, ele tomou historicamente a forma de uma exteriorização alienada [entfremdete Entäusserung], contraditoriamente (em termos dialéticos) resultando em uma "desobjetivação" ou "desefetivação" de si dos indivíduos.

Desse modo, ao contrário de Hegel, para quem toda exteriorização é uma forma de alienação, para Marx, o patológico deste processo - que pode ser lido, em linhas gerais, como um processo de inversão entre sujeito e objeto, já anunciado na passagem de Ruy Fausto anteriormente destacada - não poderia ser encontrado naquele movimento originário de exteriorização objetiva, mas em sua degradação "artificial”, histórica. Tal degradação, por seu turno, coaduna-se com o surgimento e a consolidação da propriedade privada até sua forma mais elaborada, burguesa:

O homem só não se perde em seu objeto se este lhe vem a ser como objeto humano ou homem objetivo. Isto só é possível na medida em que ele vem a ser objeto social para ele, em que ele próprio se torna ser social [gesellschaftliches Wesen], assim como a sociedade se torna ser [Wesen] para ele neste objeto. (MARX, 2004b, p. 109)

\footnotetext{
12 Essa dialética seria, mais tarde, reafirmada na primeira tese sobre Feuerbach, na qual Marx anuncia a proposta de um novo materialismo, capaz de abarcar "o lado ativo" do homem atestado pelo idealismo: "O principal defeito de todo materialismo até aqui (incluído o de Feuerbach) consiste em que o objeto, a realidade, a sensibilidade, só é apreendido sob a forma de objeto ou de intuição, mas não como atividade humana sensível, como práxis, não subjetivamente. Eis porque, em oposição ao materialismo, o aspecto ativo foi desenvolvido de maneira abstrata pelo idealismo, que, naturalmente, desconhece a atividade real, sensível, como tal. Feuerbach quer objetos sensíveis realmente distintos dos objetos do pensamento: mas não apreende a própria atividade humana como atividade objetiva. Por isso, em A essência do cristianismo, considera apenas o comportamento teórico como o autenticamente humano, enquanto que a práxis só é apreciada e fixada em sua forma fenomênica judaica e suja. Eis porque não compreende a importância da atividade 'revolucionária', 'prático-crítica'." (MARX; ENGELS, 1991, pp. 11-2)
} 
Em resumo, para Marx, o problema não se encontra já no domínio da exteriorização objetiva dos homens (este, o índice de sua própria humanidade), mas na forma pela qual os produtos de sua objetivação, de seu trabalho social, puderam ser apropriados privadamente, isto é, tornarse posse de outrem. Em outras palavras, é a partir do momento em que os produtos do trabalho são separados do trabalhador que o caráter positivo da exteriorização no mundo converte-se em "servidão" e o indivíduo social torna-se indivíduo privado, isto é, alienado.

Como determinar, então, esse fenômeno? Conforme explica Marx, pela alienação do trabalho, anverso daquela apropriação privada, o objeto ganha vida fora da relação com seu produtor. Fruto da exteriorização objetiva do homem, ele agora "existe fora dele [ausser ihm], independente dele e estranh[o] a ele, tornando-se uma potência [Macht] autônoma diante dele, [e] a vida que ele concedeu ao objeto se lhe defronta hostil e estranha" (MARX, 2004b, p. 81). O homem perde seu objeto, torna-se um ser "sem-objeto" [gegenstandlos] e, por isso, vê sua própria inserção no mundo comprometida, porquanto sua relação com o mundo é seu processo de trabalho, sua práxis, da qual ele já não pode usufruir plenamente, na medida em que seus produtos lhe foram subtraídos.

Este processo ganha, contudo, um contorno ainda mais radical, uma vez que não é apenas do fruto direto de sua atividade que ele é privado: "A objetivação tanto aparece como perda do objeto que o trabalhador é despojado dos objetos mais necessários não somente à vida, mas também dos objetos do trabalho." (MARX, 2004b, pp. 80-1) Quer dizer, não apenas aquilo que ele produz, mas os próprios meios de realização de seu trabalho (no limite, portanto, os meios de sua realização como ser humano) agora também pertencem a outro: "o trabalho mesmo se torna um objeto" (MARX, 2004b, p. 81).

Destarte, completamente despossuído de todos os meios para garantir sua sobrevivência, o homem pode ser efetivamente (socialmente) reduzido à sua mera capacidade subjetiva, pura e abstrata força de trabalho. Ao perder sua objetividade, o trabalhador torna-se indiferente às suas necessidades objetivas, mesmo àquelas mais elementares. Eis porque, como mencionado anteriormente, trata-se de compreender a alienação de que fala Marx como uma patologia no interior do processo de objetivação, mesmo sem esgotar este processo, muito pelo contrário ${ }^{13}$. A expressão maior dessa perda da dimensão objetiva de seu ser se manifesta justamente no fato de que o trabalhador alienado é privado da dimensão da necessidade, da carência:

13 Por isso, Marx constata a necessidade de "[examinar] mais de perto a objetivação, a produção do trabalhador, e nela o estranhamento, a perda do objeto, do seu produto" (MARX, 2004b, p. 81). 
Em parte, este estranhamento se mostra na medida em que produz, por um lado, o refinamento das carências e dos seus meios; por outro, a degradação brutal, a completa simplicidade rude abstrata da carência (...). Mesmo a carência de ar livre deixa de ser, para o trabalhador, carência; o homem retorna à caverna, que está agora, porém, infectada pelo mefítico [ar] pestilento da civilização, e que ele habita apenas muito precariamente, como um poder estranho que diariamente se lhe subtrai, do qual ele pode ser diariamente expulso, se não pagar ${ }^{14}$. (...). Luz, ar etc., a mais elementar limpeza animal cessam de ser, para o homem, uma carência. A imundície, esta corrupção, apodrecimento do homem, o fluxo de esgoto (isto compreendido à risca) da civilização torna-se para ele um elemento vital. O completo abandono não natural, a natureza apodrecida, tomam-se seu elemento vital. Nenhum de seus sentidos existe mais, não apenas em seu modo humano, mas também num modo não humano, por isto mesmo nem sequer num modo animal. (...) [Isto quer dizer] não apenas que o homem deixa de ter quaisquer carências humanas, [mas que] mesmo as carências animais desaparecem. $\mathrm{O}$ irlandês apenas conhece a carência do comer e efetivamente [conhece a necessidade] do comer batatas e, naturalmente, apenas batatas Lumper, a pior espécie de batatas. (MARX, 2004b, p. 140)

Essa privação da objetividade de seu ser, verdadeira "desefetivação" ou "desobjetivação de si", resulta, ainda, naquele outro aspecto da alienação referido no início: a "transferência" da própria dimensão passiva do trabalhador. Isso significa que, no modo de produção capitalista, necessidades, desejos, fruições, gozos e afetos, todas essas características propriamente humanas, são remetidas a outrem - e estranhadas pelo próprio indivíduo que as possui.

Nesse sentido, Marx observa que a relação do trabalho com o ato da produção no interior do trabalho

é a relação do trabalhador com sua própria atividade como uma [atividade] estranha não pertencente a ele, a atividade como miséria, a força como impotência, a procriação como castração. A energia espiritual e física própria do trabalhador - pois o que é vida senão atividade - como uma atividade voltada contra ele mesmo, independente dele, não pertencente a ele (MARX, 2004b, p. 83).

\footnotetext{
${ }_{14}$ Mais tarde, em O 18 Brumário, observará o autor: “A propriedade parcelária, nessa escravatura sob o capital a que conduz inevitavelmente o seu desenvolvimento, transformou a massa da nação francesa em trogloditas. Dezesseis milhões de camponeses (incluindo mulheres e crianças) vivem em cavernas, uma grande parte das quais apenas tem uma abertura, outra parte, apenas duas, e a mais favorecida apenas três aberturas. As janelas são para uma casa aquilo que os cinco sentidos são para a cabeça." (MARX, 2009, p. 328)
} 
Como nota Franck Fischbach, há aqui uma "intrusão de passividade" no trabalhador, embora esta passividade não seja a sua própria, mas imposta exteriormente. Por isso:

[A alienação] diz respeito ao fato de que o trabalhador é primeiramente desobjetivado. Reduzido à pura atividade, ele possui a objetividade e a dimensão da passividade fora dele, de modo que essa passividade, a seguir, retorna contra ele mesmo, se impõe a ele como a potência que exerce nele uma objetividade que não é mais a sua e da qual ele se separa. (FISCHBACH, 2009, p. 157, tradução nossa)

O indivíduo, assim, pode se apreender como um sujeito puramente ativo e apreender apenas o agir incessante (e não a dialética atividade/passividade, isto é, a práxis, que aponta igualmente para a dimensão social do indivíduo enquanto produtor) como a única dimensão de seu ser. Consequentemente, o trabalho alienado converte a dimensão passiva, inclusive em seu viés social - o indivíduo como indivíduo social - , em uma "transferência (estranhada) da passividade". Com efeito, agora a alienação "aparece tanto no fato de meu meio de vida ser de um outro, [quanto] no fato de que aquilo que é meu desejo ser a posse inacessível de um outro" (MARX, 2004b, p. 147).

Não à toa, lembra Marx, os economistas políticos fazem "do trabalhador um ser insensível e sem carências, assim como [fazem] de sua atividade uma pura abstração de toda atividade" (MARX, 2004b, p. 141) eis aqui o prenúncio elementar do que, mais tarde, em O capital, será conceituado como trabalho abstrato. Desde os Manuscritos econômicofilosóficos nota-se que, para Marx, a sociedade burguesa é erigida sobre contínuos processos de abstração. Por isso, nela, o homem é "desencarnado" do mundo (no linguajar fenomenológico), visado exclusivamente como capacidade subjetiva de trabalho independente de sua concretude existencial e de todos os outros indivíduos.

\section{III}

O processo de abstração real operado pelos mecanismos de reprodução do capital não permite identificar pura e simplesmente trabalho alienado e trabalho abstrato. Antes, ele denota como a sociedade burguesa é erigida e sustentada por consecutivos movimentos abstrativos reais - sendo o mais importante aquele que põe o trabalho abstrato - que só encontram espaço para se efetivar em uma sociedade estranhada de si mesma, composta por indivíduos alienados das dimensões essenciais de seu ser. Em outras palavras, a posição do trabalho abstrato (de generalidade biológica a realidade social) como fonte privilegiada de riqueza (que também, importa notar, só pode ser abstrata) só se torna 
compreensível em um regime no qual os próprios indivíduos - produtores, trabalhadores - se encontram apartados das condições de constituição de si mesmos como sujeitos. Ou seja, em que o processo de subjetivação é truncado, mutilado, unilateral; em suma, abstrato.

Nesse sentido, cumpre acrescentar que, em nosso entendimento, a dupla faceta da alienação mencionada na seção precedente, extraída dos Manuscritos econômico-filosóficos - enquanto "desobjetivação de si" e "transferência de passividade" - , não foi abandonada, mas reforçada e enriquecida nas obras posteriores, dedicadas privilegiadamente à crítica da economia política. Assim, por exemplo, nos Grundrisse, Marx assevera que o trabalho assalariado - este, o trabalho alienado par excellence - , ao mesmo tempo em que constitui a fonte de toda riqueza objetiva, representa igualmente a "pobreza absoluta" do trabalhador - pobreza não apenas material, mas enquanto esvaziamento de suas possibilidades objetivas de constituir a si mesmo como sujeito, Ser-Si. Eis o que importa explicar.

Os meios de trabalho vivo (ou seja, a matéria-prima e os instrumentos do trabalho) são classificados por Marx como a "objetividade material do trabalho vivo finalístico”. No processo de valorização,

[esses] componentes de valor do capital - dos quais um existe sob a forma do material, o outro, sob a forma do instrumento aparecem perante o trabalhador, i.e., o trabalho vivo (pois é só nesse processo que o trabalhador existe enquanto tal), não como valores, mas como simples momentos do processo de produção; como valores de uso para o trabalho, como as condições objetivas de sua eficácia, ou como seus momentos objetivos (MARX, 2011, pp. 289-90).

Nota-se aqui a separação existente a priori entre o trabalhador, sua capacidade viva de trabalho e as condições de atualização dessa capacidade. Contudo, afirma ainda Marx, durante o processo de produção, "a separação do trabalhador de seus momentos de existência objetivos instrumento e material - é superada" (MARX, 2011, p. 290). Essa superação, naturalmente, é condição necessária de efetivação do próprio processo de trabalho. Quer dizer, não há trabalho sem a apropriação daquelas condições objetivas. Entretanto:

Essa apropriação pela qual o trabalho vivo, no próprio processo de produção, faz de instrumento e material o corpo de sua alma e assim os ressuscita dos mortos na verdade está em antítese com o fato de que o trabalho é privado de objeto, ou só [é] realidade no trabalhador em sua vitalidade imediata - ao passo que o material e instrumento de trabalho existem no capital como seres por si mesmos. (MARX, 2011, p. 291)

Destarte, o valor de uso do trabalho vivo só existe para o capital na medida em que ele, como explica Franck Fischbach, "já comprou a 
capacidade de trabalho (o trabalho como capacidade abstrata e subjetiva) e, por esse meio, já a incorporou a si mesmo" (FISCHBACH, 2009, p. 163, tradução nossa) ${ }^{15}$.Tem-se aqui uma espécie de "desnaturalização" do processo vital de trabalho, isto é, da relação entre o trabalhador e o trabalho, no metabolismo entre ser humano e natureza, sujeito e objeto. Atesta Marx:

Já o fato de que o trabalho aparece perante o capital como sujeito, i.e., que o trabalhador aparece somente na determinação do trabalho, e que este não é o próprio trabalhador, tem de despertar a atenção. Nesse caso, abstraindo-se do capital, já existe uma ligação, uma relação do trabalhador com sua própria atividade que de maneira alguma é a relação "natural", mas que já contém ela própria uma determinação econômica específica. (MARX, 2009, p. 243)

Assim, o processo de trabalho não aparece ao trabalhador como momento de realização de si [Selbstverwirklichung], de confirmação da objetivação de si enquanto indivíduo vivo. Pelo contrário, o trabalhador nele adentra como mero possuidor de uma capacidade abstrata de trabalho. Como novamente aponta Fischbach, isso "supõe que a separação entre, de uma parte, o trabalhador como indivíduo vivo e, de outra, dessa força ou capacidade que ele possui, que ele tem, mas que ele não é, e que não é ele, já esteja realizada" (FISCHBACH, 2009, p. 165, tradução nossa).

Ora, o que se extrai daí nada mais é do que outro anúncio daquele processo de abstração real (FISCHBACH, 2009, p. 166) que Marx retomará no primeiro capítulo de $\mathrm{O}$ capital. Antes disso, nos Grundrisse, o autor já observa que, do ponto de vista da objetividade, o trabalho é algo ainda não-objetivado, "é não matéria-prima, não instrumento de trabalho, não produto bruto: trabalho separado de todos os meios e objetos de trabalho, separado de toda sua objetividade" (MARX, 2011, p. 229). Em suma, é uma pura essência separada de sua efetiva existência. Mas precisamente esse "trabalho vivo existindo como abstração desses momentos de sua efetividade", quer dizer, "esse completo desnudamento do trabalho, existência puramente subjetiva, desprovida de toda objetividade [é] pobreza absoluta: pobreza não como falta, mas como completa exclusão da riqueza objetiva (MARX, 2011, p. 229-30). Riqueza esta tanto material quanto espiritual, poderíamos acrescentar.

Importa ainda destacar que a noção de "pobreza absoluta" do trabalho capitalista se relaciona aqui, diretamente, com o fato de que o

15 Acrescenta Fischbach: "Comprando o trabalho enquanto simples capacidade ou faculdade, o capital já comprou, igualmente, o uso que fará do trabalho, de sorte que se a separação entre a capacidade subjetiva e a objetiva é abolida na sequência, no processo de produção, essa abolição se identifica ao próprio uso que o capital faz da capacidade de trabalho. Ela ocorre, portanto, para o capital, não para o próprio trabalhador." (FISCHBACH, 2009, p. 163, tradução nossa) 
trabalho é "o não valor existente" (MARX, 2011, p. 230). É que, ao entrar no processo de troca com o capitalista, o trabalhador não vende nenhuma riqueza; "só vende a disposição temporária sobre sua capacidade de trabalho" (MARX, 2011, p. 228). Esta, porém, embora fonte de valorização das coisas, sai do processo de produção da mesma forma como entrou - ou seja, a ela não é acrescentado nenhum valor:

O trabalhador se defronta com o capitalista não como valor de troca, mas é o capitalista que se defronta com ele como valor de troca. A sua ausência de valor e sua desvalorização são o pressuposto do capital e a condição do trabalho livre de modo geral. (MARX, 2011, p. 226)

Essa ausência de valor - de troca - , acrescida ao fato de que o valor de uso do trabalhador não se refere a si mesmo, mas às suas capacidades e faculdades, à sua abstrata força de trabalho, permite a introdução de uma cisão entre, de um lado, o trabalhador enquanto indivíduo vivo e, de outro, enquanto pessoa jurídica, entre o ser e o fazer do trabalhador, entre aquilo que ele é e aquilo que ele faz (FISCHBACH, 2009, pp. 170-1). Enquanto "sujeito livre", ou seja, como pessoa jurídica, ele cede um direito momentâneo sobre o uso de suas forças, sem que isso represente a cessão de um direito sobre si mesmo:

Doravante, o trabalho é, para o trabalhador, uma atividade à qual ele se entrega sem identificá-la, porém, a seu próprio ser. Por isso também o trabalho é, para ele, apenas um meio que utiliza e do qual dispõe livremente. O trabalho é um meio que ele utiliza para sua vida, mas com o qual sua vida não se identifica. (FISCHBACH, 2009, p. 171, tradução nossa) 16

O trabalhador é reduzido, portanto, a um possuidor de uma mercadoria - a saber, sua própria capacidade de trabalho, um conjunto de disposições físicas e mentais que serão postas em marcha pelo e para o capital, isto é, para a produção de riqueza objetiva. Dessa forma, uma contradição se evidencia na relação capital/trabalho entre o trabalho como "pobreza absoluta" e substância de valorização ${ }^{17}$, portanto, do capital ${ }^{18}$. A

16 Neste ponto, vale recuperar o que dizia Marx já nos Manuscritos econômico-filosóficos: "O trabalhador só se sente, por conseguinte e em primeiro lugar, junto a si [quando] fora do trabalho e fora de si [quando] no trabalho. (...) O trabalho não é, por isso, a satisfação de uma carência, mas somente um meio para satisfazer necessidades fora dele." (MARX, 2004b, p. 83)

17 "O material natural puro, se não tem nenhum trabalho humano nele objetivado, se, portanto, é matéria pura que existe independente do trabalho humano, não tem nenhum valor, visto que valor é simplesmente trabalho objetivado." (MARX, 2011, p. 292)

18 "O trabalho não como objeto, mas como atividade; não como valor ele mesmo, mas como a fonte viva do valor. A riqueza universal, perante o capital, no qual ela existe de forma objetiva como realidade, como possibilidade universal do capital, possibilidade que se afirma enquanto tal na ação. Portanto, de nenhuma maneira se contradiz a proposição de que o trabalho é, por um lado, a pobreza absoluta como objeto e, por outro, a possibilidade universal da riqueza como sujeito e como atividade, ou, melhor dizendo, essas proposições inteiramente contraditórias condicionam-se mutuamente e resultam da 
passagem a seguir, conquanto longa, sintetiza os meandros da contradição destacada:

o ser-para-si autônomo do valor perante a capacidade de trabalho - daí sua existência como capital -, a indiferença objetiva autossuficiente, a estranheza das condições objetivas do trabalho perante a capacidade de trabalho viva, (...) chega ao ponto em que essas condições confrontam a pessoa do trabalhador na pessoa do capitalista - como personificações com vontade e interesse próprios -, essa dissociação, separação absoluta entre a propriedade, i.e., as condições materiais do trabalho, e a capacidade de trabalho viva, condições materiais que se confrontam com ela como propriedade alheia, como a realidade de outra pessoa jurídica, como território absoluto da vontade dessa pessoa - e que, por outro lado, o trabalho aparece consequentemente como trabalho alheio perante o valor personificado no capitalista ou perante as condições objetivas de trabalho - , essa separação absoluta entre propriedade e trabalho, entre a capacidade de trabalho viva e as condições de sua realização, entre trabalho objetivado e vivo, entre o valor e a atividade criadora de valor daí também a estranheza do conteúdo do trabalho para o próprio trabalhador - , esse divórcio agora aparece igualmente como produto do próprio trabalho, como concretização, como objetivação de seus próprios momentos. Pois, pelo próprio novo ato de produção - que só confirma a troca entre capital e trabalho vivo que lhe antecede - , o trabalho excedente e, em consequência, o valor excedente, o produto excedente, enfim, o resultado total do trabalho (tanto do trabalho excedente como do necessário) foram postos como capital, como valor de troca confrontando de maneira autônoma e indiferente a capacidade de trabalho viva, ou confrontando-a como seu mero valor de uso. A capacidade de trabalho se apropriou unicamente das condições subjetivas do trabalho necessário - os meios de subsistência para a capacidade de trabalho produtora, i.e., sua reprodução como mera capacidade de trabalho separada das condições de sua efetivação - e pôs essas próprias condições como coisas, valores, que a confrontam em uma personificação estranha e dominante. A capacidade de trabalho não sai mais rica do processo, sai mais pobre do que nele entrou. Pois não só fabricou as condições do trabalho necessário como condições pertencentes ao capital, mas a valorização inerente a ela como possibilidade, possibilidade de criação de valor, que agora existe igualmente como valor excedente, produto excedente, em uma palavra, como capital, como domínio sobre a capacidade de trabalho viva, como valor dotado de poder e vontade próprios, confrontando-a em sua pobreza abstrata, inobjetiva, puramente

essência do trabalho, pois é pressuposto pelo capital como antítese, como existência antitética do capital e, de outro lado, por sua vez, pressupõe o capital." (MARX, 2011, p. 230) 
subjetiva. A capacidade de trabalho viva produziu não só a riqueza alheia e a própria pobreza, mas também a relação entre essa riqueza, como riqueza que se relaciona consigo mesma, e ela própria, como a pobreza de cujo consumo a riqueza extrai para si novas energias vitais e se valoriza outra vez. Tudo isso resulta da troca, em que sua capacidade de trabalho viva trocouse por um quantum de trabalho objetivado, só que agora esse trabalho objetivado - essas condicões de sua existência existindo fora dela e o estar-fora-dela autônomo dessas condições objetivas - aparece como seu próprio produto, posto por ela mesma, tanto como sua própria objetivação quanto como sua objetivação enquanto um poder dela própria independente, poder que antes a domina, a domina por meio de sua própria ação (MARX, 2011, p. 371-2).

Em suma, a força de trabalho se dirige ao processo de trabalho como àquilo que lhe permitiria acessar as condições objetivas de realização das quais está desprovida. Entretanto, ela o experimenta

como o processo de sua des-realização e desobjetivação. Ela descobre que sua não-objetividade inicial é, na realidade, o produto e o resultado do processo no qual se engajou para entrar em contato com as condições objetivas de sua própria realização (FISCHBACH, 2011, p. 191, tradução nossa).

Nessa linha, arremata Marx:

Considerado do ponto de vista do trabalho, o trabalho vivo aparece funcionando no processo de produção de tal modo que afasta de si sua realização nas condições objetivas como realidade alheia e, por conseguinte, põe a si mesmo como mera capacidade de trabalho carente e privada de substância diante dessa realidade estranhada, que não pertence a ele, mas a outro; que põe sua própria realidade não como um ser para si, mas como mero ser para outro e também, portanto, como mero seroutro, ou ser do outro contra si mesmo. Esse processo de realização é igualmente o processo de desrealização do trabalho. O trabalho põe-se objetivamente, mas põe essa sua objetividade como seu próprio não ser ou como o ser do seu não ser - do capital. O trabalho retoma a si como pura possibilidade do pôr valor ou da valorização; porque toda a riqueza efetiva, o mundo do valor efetivo e, da mesma forma, as condições reais de sua própria valorização são postos diante dele como existências autônomas. São as possibilidades latentes no próprio seio do trabalho que, em virtude do processo de produção, existem fora dele como efetividades - mas como efetividades que lhe são alheias - , que constituem a riqueza em oposição ao trabalho. (MARX, 2011, p. 373) 
O vínculo intrínseco entre o processo de abstração que permite a posição do trabalho abstrato enquanto fonte de riqueza e o processo de abstração que sustenta o fenômeno da alienação, por meio do qual os indivíduos estranham seu próprio mundo objetivo e se veem impedidos de se constituírem plenamente enquanto sujeitos, parece definido, ao menos nos limites impostos a um trabalho de pequena envergadura como este.

Antes, contudo, de verificar o grau em que a explicação marxiana do fenômeno da alienação pode ressoar contemporaneamente, convém ainda esclarecer um aspecto importante daquele conceito como aparece em $\mathrm{O}$ capital. No Capítulo XXI desta obra, Marx retoma a descrição da alienação desde a perspectiva da "perda de objeto", em linha bastante semelhante àquela observada nos Grundrisse:

A separação entre o produto do trabalho e o próprio trabalho, entre as condições objetivas do trabalho e sua força subjetiva de trabalho, era a base realmente dada, o ponto de partida do processo de reprodução capitalista. Mas o que era, no princípio, apenas ponto de partida, é produzido e perpetuado sempre de novo, por meio da mera continuidade do processo, da reprodução simples ${ }^{19}$, como resultado próprio da produção capitalista. Por um lado, o processo de produção transforma continuamente a riqueza material em capital, em meios de valorização e de satisfação para o capitalista. Por outro, o trabalhador sai do processo sempre como nele entrou - fonte pessoal de riqueza, mas despojado de todos os meios para tornar essa riqueza realidade para si. Como, ao entrar no processo, seu próprio trabalho já está alienado dele, apropriado pelo capitalista e incorporado ao capital, este se objetiva, durante o processo, continuamente em produto alheio. Como o processo de produção é, ao mesmo tempo, o processo de consumo da força de trabalho pelo capitalista, o produto do trabalhador transforma-se continuamente não só em mercadoria, mas em capital, em valor que explora a força criadora de valor, em meios de subsistência que compram pessoas, em meios de produção que empregam o produtor. $\mathrm{O}$ próprio trabalhador produz, por isso, constantemente a riqueza objetiva como capital, como poder estranho, que o domina e explora, e o capitalista produz de forma igualmente contínua a força de trabalho como fonte subjetiva de riqueza, separada de seus próprios meios de objetivação e realização, abstrata, existente na mera corporalidade do trabalhador, numa só palavra, o trabalhador como trabalhador assalariado. Essa constante reprodução ou perpetuação do trabalhador é a condição sine qua non da produção capitalista. (MARX, 1996, pp. 203-4)

19 Vale ressaltar que o processo alienante verificado na reprodução simples é expandido para a totalidade da sociedade burguesa por meio da reprodução ampliada do capital. 
Até aqui, não há grandes novidades. Antes, porém, no primeiro capítulo, no bojo da discussão sobre a mercadoria e logo após tratar do duplo caráter do trabalho e sua consequência para a teoria do valor, Marx descreve o caráter fetichista que a forma mercadoria assume na sociedade burguesa. Ao fazê-lo, demonstra outra faceta da alienação - não enquanto "perda do objeto", mas como "transferência de passividade" - que se realiza em uma esfera diferente, complementar à da produção: a da troca, do mercado.

De acordo com Marx, tão logo um objeto qualquer seja convertido em mercadoria - isto é, posto no processo de intercâmbio mercantil, ele "se transforma numa coisa fisicamente metafísica" (MARX, 1988, p. 70). Com efeito, há um caráter enigmático na forma mercadoria que, por assim dizer, concede a seu possuidor características místicas, a rigor não encontradas na própria mercadoria, mas que só podem ser entendidas por meio do processo de abstração real que, como insistimos, sustenta a produção capitalista.

Nesse processo, as relações sociais, humanas, são substituídas pelas relações dos produtos da atividade humana - isto é, de sua exteriorização objetiva - e, por isso, aparecem de modo estranhado, como sujeitos dotados de qualidades especiais, suprassensíveis:

O misterioso da forma mercadoria consiste, portanto, simplesmente no fato de que ela reflete aos homens as características sociais de seu próprio trabalho como características objetivas dos próprios produtos do trabalho, como propriedades naturais sociais dessas coisas e, por isso, também reflete a relação social dos produtores com o trabalho total como uma relação social existente fora deles, entre objetos. Por meio desse quiproquó os produtos do trabalho se tornam mercadorias, coisas físicas metafísicas ou sociais. (...) a forma mercadoria e a relação de valor dos produtos de trabalho, na qual ele se representa, não têm que ver absolutamente nada com sua natureza física e com as relações materiais que daí se originam. Não é mais nada que determinada relação social entre os próprios homens que para eles aqui assume a forma fantasmagórica de uma relação entre coisas. Por isso, para encontrar uma analogia, temos de nos deslocar à região nebulosa do mundo da religião. Aqui, os produtos do cérebro humano parecem dotados de vida própria, figuras autônomas, que mantêm relações entre si e com os homens. Assim, no mundo das mercadorias, acontece com os produtos da mão humana. Isso eu chamo o fetichismo que adere aos produtos de trabalho, tão logo são produzidos como mercadorias, e que, por isso, é inseparável da produção de mercadorias. (MARX, 1988, p. 71)

Destarte, surge "uma sociedade de produtores de mercadorias, cuja relação social geral de produção consiste em relacionar-se com seus 
produtos como mercadorias, portanto como valores, e nessa forma reificada relacionar mutuamente seus trabalhos privados como trabalho humano igual” (MARX, 1988, p. 75). A imposição da lógica mercantil sobre as relações humanas, isto é, a alienação convertida em reificação ${ }^{20}$, faz que "os homens tenham doravante necessidade da mediação das coisas como mercadorias para realizar essa dimensão essencial e própria de sua existência que são as relações sociais inter-humanas"' (FISCHBACH, 2009, p. 93, tradução nossa) ${ }^{21}$.

Assim, a produção de mercadorias enseja a existência de relações sociais entre coisas e, por conseguinte, de relações coisificadas ou reificadas entre pessoas. E essa inversão torna-se possível por conta da "conduta meramente atomística dos homens em seu processo de produção social” (MARX, 1988, p. 85).

Quer dizer, em uma sociedade na qual as trocas dos produtos do trabalho são mediadas pelo mecanismo de mercado, a produção só pode ser privada. Bem entendido, contudo, o adjetivo aqui empregado não denota uma ausência de relações com outrem. Na verdade, "os trabalhos são privados na medida em que não satisfazem uma necessidade social de maneira direta, mas apenas de forma indireta, por intermédio da troca mercantil"' (FISCHBACH, 2009, p. 202, tradução nossa).

Por conseguinte, a produção de mercadorias implica uma relação impessoal entre pessoas. Cada um produz para satisfazer à necessidade de outro, e seu contato com este outro ocorre apenas no momento da troca:

Para cada um, na medida em que ele não produz para si mesmo, sua produção só adquire sentido com a condição de que seja sem dificuldade orientada para a troca. Portanto, com a condição de que ela integre, desde o início, a troca mercantil como sua realização necessária e natural. (FISCHBACH, 2009, p. 203, tradução nossa)

Desse modo, o indivíduo se relaciona com todos os outros enquanto intercambista, não como produtor. Na dinâmica da troca mercantil, lócus privilegiado da dimensão alienante da transferência de passividade ${ }^{22}$, como explica Franck Fischbach,

de uma parte, cada um trabalha ao preço de uma transferência de suas próprias necessidades a um outro que trabalha para lhes satisfazer sem o saber e, de outra parte, cada um trabalha em

\footnotetext{
20 Pois se trata de "uma formação social em que o processo de produção domina os homens, e ainda não o homem o processo de produção" (MARX, 1988, p. 76).

${ }^{21}$ Como também explica Lucien Sève, "a alienação não diz respeito apenas aos indivíduos, mas igualmente - e mesmo primeiramente, do ponto de vista lógico - às relações sociais no seio das quais eles vivem, melhor dizendo, ela é justamente a clivagem generalizada entre os indivíduos e suas relações, tornadas assim potências sociais incontrolavelmente autônomas" (SĖVE, 2012, p. 41, tradução nossa).

22 Conforme aponta Fischbach, é possível remeter aqui àquilo que Slavoj Zizek denomina de "sujeito interpassivo" (cf. FISCHBACH, 2009, pp. 158-9; ZIZZK, 2018).
} 
vista de satisfazer necessidades que não pode experimentar enquanto tais, na medida em que elas são necessidades de um outro. A sociedade mercantil supõe, assim, que ninguém seja realmente afetado por suas próprias carências, pois cada produtor se coloca no trabalho apenas em vista de satisfazer as necessidades de outros, graças à troca e, portanto, diferenciando a satisfação de suas próprias necessidades, que deverá esperar, para ocorrer, que ele tenha produzido algo para trocar. (FISCHBACH, 2009, p. 204, tradução nossa)

Por fim, essa transferência de passividade, que constitui a alienação própria à esfera mercantil, isto é, o fato de a produção não ser motivada pela experiência passiva da própria necessidade, mas pelo intercâmbio com outro, indeterminado, desemboca em um mecanismo de troca no qual a relação entre as pessoas aparece mediada pela relação entre coisas. Um processo de afetos recíprocos que não ocorre entre indivíduos, mas entre mercadorias. Logo, um processo de abstração do ser dos próprios sujeitos como indivíduos sociais.

Finda essa passagem por Marx, é agora possível deslocar nossa atenção para a análise da pertinência de suas observações acerca do trabalho alienado - e sua posição social desde o processo de abstração real operado pelo capitalismo - para a conjuntura presente. Logo, constituir, a partir desse confronto, um primeiro horizonte teórico desde o qual o projeto de uma "fenomenologia da vida alienada" na contemporaneidade poderia se efetivar.

Neste quadro, será tomada como parâmetro heurístico-conceitual a obra La nouvelle raison du monde - essai sur la société néolibérale, de Pierre Dardot e Christian Laval. A escolha se explica pelo seguinte motivo: neste livro instigante, os autores buscam investigar o caráter específico do desenvolvimento capitalista das últimas décadas - comumente chamado de neoliberalismo - com o intuito de perscrutar as mudanças sociais/culturais que permitiram a emergência de uma nova racionalidade capaz de "fazer do mercado o princípio de governo dos homens [e] de si" (DARDOT; LAVAL, 2009, p. 21, tradução nossa).

Não obstante a explícita inspiração foucaultiana da obra, é igualmente nítido que a contribuição destes autores se encaminha na direção de nossa interpretação da ideia de alienação extraída da letra de Marx, como se verá na sequência. Por isso, entendemos que pela análise dessa obra, mais precisamente do capítulo intitulado La fabrique du sujet néolibéral, será possível traçar em grandes linhas as formas assumidas 
pelo fenômeno da alienação na experiência vivida, concreta, dos indivíduos vivos.

Nosso intuito, com o auxílio dos pensadores supramencionados, é mostrar que a figura do sujeito puramente ativo, privado de toda objetividade, e mesmo (abstratamente) exterior a ela - figura que, como vimos, Marx denuncia desde os Manuscritos econômico-filosóficos e cuja formação enriquece nos Grundrisse e em O capital - , representa a Gestalt da alienação típica de nossa era, "aquela que o capitalismo nos preparava desde seu início, mas que apenas hoje aparece como indispensável a seu funcionamento e a sua perpetuação" (FISCHBACH, 2011, p. 310, tradução nossa). Numa palavra, a figura daquilo que Dardot e Laval denominam néosujet, neossujeito.

No período neoliberal, as novas exigências econômicas da reprodução capitalista ${ }^{23}$ criam formas originais de constituição subjetiva, adequada aos ditames de perpetuação das relações de produção vigentes. Em nossa era, constatam Dardot e Laval:

Não se trata mais tanto de reconhecer que o homem no trabalho permanece um homem, que ele não se reduz jamais ao estatuto de um objeto passivo [um ser de carências, poderíamos dizer, à luz de Marx - VS]. Trata-se de ver nele o sujeito ativo que deve participar totalmente, engajar-se plenamente, entregar-se inteiramente em sua atividade profissional. (DARDOT; LAVAL, 2009, p. 408, tradução nossa)

Nesse sentido, observam, a antiga incidência de um discurso multifacetado sobre o sujeito moderno - agente político, homem econômico, pessoa de direitos jurídicos etc. - cedeu espaço a um discurso rigorosamente unificado. O sujeito unitário neoliberal é o sujeito da "implicação total de si" - o indivíduo "empreendedor", que transpõe para seu plano privado a mesma lógica e racionalidade que presidem a vida empresarial:
É o indivíduo performático e competitivo que procura maximizar seu capital humano em todos os domínios, que não procura apenas se projetar no futuro e calcular seus ganhos e custos como o antigo homem econômico, mas que visa, sobretudo, a trabalhar sobre si mesmo a fim de se transformar em permanência, de se melhorar, de se tornar sempre mais eficaz. (DARDOT; LAVAL, 2009, p. 414, tradução nossa)

Segundo os autores, esse movimento resulta em um novo ethos, típico da nossa quadra, na qual o indivíduo converte-se em um "microcosmo" harmônico com o mundo da administração empresarial e o "macrocosmo" do mercado mundial globalizado (DARDOT; LAVAL, 2009,

23 Que podem ser pensadas, no plano econômico, nos moldes daquilo que David Harvey classificou, em seu célebre estudo sobre a Condição pós-moderna, como acumulação flexível do capital. (cf. HARVEY, 2008, pp. 115-84). 
p. 424, tradução nossa). Consequentemente, aquilo que se poderia hoje chamar "gestão neoliberal de si mesmo", tal como a gestão das empresas, "consiste em fabricar um eu performático, que exige sempre mais de si" (DARDOT; LAVAL, 2009, p. 425, tradução nossa).

De fato, a norma da sociedade neoliberal é "ultrapassar os seus limites". Como também assinala o filósofo germano-sul-coreano Byung Chul-Han (2017), vivemos em uma sociedade que a todo momento exerce sobre si mesma um esforço que visa a fazer crer a seus membros que nada é impossível. Logo, a "máxima performance" (e não o equilíbrio, a mediania) se torna o alvo da "reestruturação pessoal" que cada um deve operar sobre si para se adequar à dinâmica da vida competitiva:

A máquina econômica, mais do que nunca, não pode funcionar pelo equilíbrio, e menos ainda pela perda. É preciso que ela vise a um "além", um "mais" [plus], que Marx havia identificado com a "mais-valia". Essa exigência própria ao regime de acumulação do capital não havia, até aqui, desdobrado o conjunto de seus efeitos. É coisa feita quando a implicação subjetiva é tal que, doravante, a procura desse "além de si" é a condição de funcionamento, tanto dos sujeitos quanto das empresas. Daí o interesse na identificação do sujeito como empresa de si e como capital humano: é justamente a extração de um "mais-de-gozar" [plus de jouir], arrancado de si mesmo, de seu prazer de viver, do simples fato de viver, que faz funcionar o novo sujeito e o novo sistema de concorrência. Subjetivação "contábil" e subjetivação "financeira" definem, em última análise, uma subjetivação pelo excesso de si sobre si, ou ainda pelo ultrapassar indefinido de si. Desenha-se, desde então, uma figura inédita da subjetivação. Não uma "transubjetivação", o que implicaria visar a um além do si que consagraria uma ruptura consigo e uma renúncia a si. Tampouco uma "autossubjetivação", pela qual se procuraria atingir uma relação ética consigo independente de qualquer outra finalidade, de tipo político ou econômico. De certo modo, trata-se de uma "ultrassubjetivação", cujo objetivo não é um estado último e estável de "posse de si", mas um além de si sempre repelido, e que é, ademais, constitucionalmente ordenado, em seu próprio regime, à lógica da empresa e, para além, ao "cosmos" do mercado mundial. (DARDOT; LAVAL, 2009, p. 437, tradução nossa)

Com isso, a lógica normativa neoliberal não precisa exigir uma renúncia de si do indivíduo em favor de alguma entidade abstrata ou coletiva. Enquanto nas fases precedentes de desenvolvimento capitalista todos os agentes "perdiam" algo, ainda que em níveis diversos - o capitalista, o gozo assegurado de seus bens por conta dos riscos assumidos ao investir seu capital; o trabalhador, a livre disposição de seu tempo e de seu corpo - , agora, todos (supostamente) "ganham". Isso porque, como 
assinalam Dardot e Laval, o sujeito neoliberal é, ao mesmo tempo e em novos parâmetros, trabalhador e acionista de seu "capital”. Quer dizer:

é o trabalhador que acumula capital e o acionista que dele desfruta. Ser seu próprio trabalhador e seu próprio acionista, "performar" sem limites e desfrutar sem entraves dos frutos de sua acumulação, tal é o imaginário da condição neossubjetiva (DARDOT; LAVAL, 2009, p. 453, tradução nossa).

Convém aqui chamar a atenção para a noção de imaginário, pela qual é possível conectar o diagnóstico dos autores franceses àquilo exposto anteriormente acerca da relação entre abstração e alienação em Marx. Evidentemente, todo esse processo de subjetivação, aqui apenas descrito rudimentarmente, não anula a cisão social que sustenta o capitalismo; pelo contrário, reforça-a e, ato contínuo, reforça também o estranhamento, a alienação:

Pois o efeito procurado pelas novas práticas de fabricação e gestão do novo sujeito é fazer que o indivíduo trabalhe para a empresa como se trabalhasse para si mesmo, suprimindo, assim, todo sentimento de alienação, e mesmo toda distância entre o indivíduo e a empresa que o emprega. Este último deve trabalhar por sua própria eficácia, intensificar seu esforço, como se essa conduta viesse de si mesmo, como se ele se comandasse desde o interior pela ordem imperiosa de seu próprio desejo, diante do qual não estaria em questão resistir. As novas técnicas da "empresa de si" chegam, sem dúvida, ao cerne da alienação pretendendo suprimir todo sentimento de alienação. Obedecer a seu desejo e ao Outro que fala com voz baixa dentro de si é uma e a mesma coisa. (DARDOT; LAVAL, 2009, pp. 408-9, tradução nossa)

O que entendemos, enfim, é que esta descrição, se tem validade, só é passível de ser compreendida à luz do processo de abstração real exposto anteriormente, que não se restringe à esfera econômica (embora seja a partir de sua posição nesta esfera, por meio do trabalho abstrato, que ela inicialmente se revele) e que permite, do ponto de vista subjetivo, a constituição de "sujeitos abstratos", sem-objeto, desefetivados, sobre os quais os referidos processos de neossubjetivação podem operar ${ }^{24}$. Tais

24 Segundo Fischbach, a "ultrassubjetividade" cria o "ser-por-projeto", "estágio supremo do ser-sem-objeto". É o sujeito que, desvinculado de qualquer laço de efetividade com o mundo objetivo, encontra-se sempre a postos para se engajar e desengajar-se em uma nova empreitada (profissional, pessoal etc.) (cf. FISCHBACH, 2009, pp. 254-7). De certo modo, Marx prenunciava esta situação, precisamente diante do esvaziamento de concretude do trabalho sobre o qual opera a valorização do capital. Assim, no Capítulo VI - inédito de O capital, dizia: "ao operário, é-lhe igualmente indiferente o conteúdo particular do seu trabalho. O seu trabalho pertence ao capital, não é mais do que o valor de uso da mercadoria que ele, operário, vendeu e vendeu-a unicamente para se apropriar de dinheiro e, mediante este, de meios de subsistência. A mudança no gênero de trabalho só lhe interessa na medida em que todo o tipo particular de trabalho exige um desenvolvimento distinto da capacidade de trabalho. Quando a sua indiferença em 
figuras nada mais são do que as novas expressões da alienação capitalista, tal como descritas por Marx, em um momento de radicalização sem precedentes do processo de abstração real dos indivíduos em relação a eles próprios e seus processos de subjetivação ${ }^{25}$.

Diante do que se expôs anteriormente, vale ainda acrescentar, equivoca-se o já mencionado Byung Chul-Han em seu interessante Sociedade do cansaço quando afirma a obsolescência da noção marxiana clássica de alienação em face do capitalismo globalizado:

A revolução clássica tinha como meta superar as relações de alienação do trabalho. Alienação significa que no trabalho o trabalhador já não reconhece a si mesmo. Segundo Marx, o trabalho é uma contínua autodesrealização. Hoje, vivemos uma época pós-marxista. No regime neoliberal a exploração tem lugar não mais como alienação e autodesrealização, mas como liberdade e autorrealização. Aqui não entra o outro como explorador, que me obriga a trabalhar e me explora. Ao contrário, eu próprio exploro a mim mesmo de boa vontade na fé de que possa me realizar. E eu me realizo na direção da morte. Otimizo a mim mesmo para a morte. Nesse contexto não é possível haver nenhuma resistência, levante ou revolução. (HAN, 2017, p. 116)

Sem adentrar em suas temerárias implicações políticas, convém apenas esclarecer que Han tece essa passagem à luz da ideia de que, contemporaneamente, vivemos em uma sociedade que sofre de "excesso de positividade", uma "sociedade de desempenho", cuja elasticidade dissolve toda negatividade, toda diferença. A liberdade do indivíduo, neste contexto, adquire o ar paradoxal de uma liberdade para coação de si mesmo:

relação ao conteúdo particular do trabalho não lhe proporciona a faculdade de trocar sem mais a sua capacidade de trabalho manifesta a sua indiferença em relação aos que o substituem, à geração seguinte, conforme as exigências do mercado. Quanto mais desenvolvida estiver a produção capitalista num país, tanto maior é a procura de versatilidade na capacidade de trabalho, tanto mais indiferente é o operário em relação ao conteúdo particular do seu trabalho e tanto mais fluido o movimento de capital que passa de uma esfera produtiva para outra." (MARX, 2004a, p. 81)

25 Em linha semelhante, Giorgio Agamben observa, em O que é um dispositivo?, que a imensa proliferação de dispositivos na contemporaneidade gerou uma multiplicidade de processos de subjetivação - ou, mais a rigor, de dessubjetivação - na medida em que não produzem sujeitos reais, mas sujeitos "espectrais": "o que define os dispositivos com os quais temos que lidar na fase atual do capitalismo é que eles não agem mais tanto pela produção de um sujeito, quanto pelos processos que podemos chamar de dessubjetivação. Um momento dessubjetivante estava certamente implícito em todo processo de subjetivação e o Eu penitencial se constituía, havíamos visto, através da própria negação; mas o que acontece nesse momento é que os processos de subjetivação e os processos de dessubjetivação parecem reciprocamente indiferentes e não dão lugar à recomposição de um novo sujeito, se não em forma larvar e, por assim dizer, espectral" (AGAMBEN, 2005, p. 15). Como acrescenta Franck Fischbach: "Poder viver e experimentar uma grande variedade de modos de subjetivação ao mesmo tempo é também não viver, nem experimentar verdadeiramente nenhum." (FISCHBACH, 2009, p. 33, tradução nossa) 
O sujeito de desempenho está livre da instância externa de domínio que o obriga a trabalhar ou que poderia explorá-lo. É senhor e soberano de si mesmo. Assim, não está submisso a ninguém ou está submisso apenas a si mesmo. É nisso que ele se distingue do sujeito de obediência [sujeito das "sociedades disciplinares" de Foucault ${ }^{26}$, típicas do capitalismo industrial VS]. A queda da instância dominadora não leva à liberdade. Ao contrário, faz com que liberdade e coação coincidam. Assim, o sujeito de desempenho se entrega à liberdade coercitiva ou à livre coerção de maximizar o desempenho. O excesso de trabalho e desempenho agudiza-se numa autoexploração. Essa é mais eficiente que uma exploração do outro, pois caminha de mãos dadas com o sentimento de liberdade. O explorador é ao mesmo tempo o explorado. Agressor e vítima não podem mais ser distinguidos. Essa autorreferencialidade gera uma liberdade paradoxal que, em virtude das estruturas coercitivas que lhe são inerentes, se transforma em violência. Os adoecimentos psíquicos da sociedade de desempenho são precisamente as manifestações patológicas dessa liberdade paradoxal. ${ }^{27}$ (HAN, 2017, pp. 29-30)

Ora, o que o filósofo sul-coreano não percebe é que este movimento só é possível em uma sociedade operada sobre a base da efetiva abstração da concretude dos indivíduos e de seus trabalhos, de seu espírito (moldado por uma racionalidade obtusa ${ }^{28}$ ) e seus corpos (um dos lócus notórios de expressão da competitividade e da performance $\left.{ }^{29}\right)$. E que, portanto, não há contradição essencial entre: a) o sujeito “sem-objeto" [gegenstandlos] de que tratava Marx, isto é, o indivíduo para quem o mundo objetivo aparece como um mundo estranho; b) o "ultrassujeito" contemporâneo de Dardot e Laval, que, como buscamos mostrar, representa um desdobramento

\footnotetext{
${ }^{26}$ A título de curiosidade, vale notar que já Marx, no Capítulo VI - inédito de O capital, por exemplo, apontava para a necessidade de "disciplina e vigilância" na produção capitalista para que ela pudesse lograr êxito (cf. MARX, 2004a, p. 51).

27 Neste ponto, Han acrescenta uma nota que vale ser reproduzida: "Em seu sentido verdadeiro, a liberdade está ligada com a negatividade. E sempre uma liberdade da coação que provém do outro imunológico. Onde a negatividade cede lugar ao excesso de positividade [o Outro se reduz ao Mesmo - VS], desaparece também a ênfase da liberdade, que surge dialeticamente à negação da negação." (HAN, 2015, p. 30 - nota) ${ }_{28}$ Nesse sentido, a depressão surge como uma manifestação privilegiada da patologia da vida contemporânea - o que chamamos de "vida alienada". Diz Han: "[A depressão] irrompe no momento em que o sujeito de desempenho não pode mais poder. Ela é de princípio um cansaço de fazer e de poder. A lamúria do indivíduo depressivo de que nada é possível só se torna possível numa sociedade que crê que nada é impossível. Não-maispoder-poder leva a uma autoacusação destrutiva e a uma autoagressão. O sujeito de desempenho encontra-se em guerra consigo mesmo. O depressivo é o inválido dessa guerra internalizada. A depressão é o adoecimento de uma sociedade que sofre sob o excesso de positividade. Reflete aquela humanidade que está em guerra consigo mesma." (HAN, 2017, p. 29) Nesse sentido, também cf. Dardot; Laval (2009, pp. 446-8).

29 Basta observar a expansão da lógica do esporte de alto rendimento, nas últimas décadas, como modelo de relação do indivíduo com seu corpo e com os outros (cf. EHRENBERG, 2010).
} 
perverso do primeiro; e c) o "sujeito de desempenho" descrito pelo próprio Han em termos não casualmente muito próximos àqueles dos autores de La nouvelle raison du monde.

Em última análise, trata-se, como dito acima, de figuras provenientes do caráter alienado do trabalho e, por conseguinte, da forma prismática ${ }^{30}$, multidirecional, como os indivíduos, sempre mediados por suas posições de classe distintas, vivenciam essa alienação ${ }^{31}$. Nesse sentido, cumpre notar que, em nosso entendimento, a autocoerção para a maximização do desempenho só é possível em uma sociedade na qual, de início, os indivíduos devem ser cindidos da objetividade na qual podem se reconhecer e se realizar, isto é, constituírem-se a si mesmos como indivíduos humanos, indivíduos sociais. Isso porque a autocoerção só pode operar em indivíduos estranhos a si mesmos, à sua natureza e às suas possibilidades e impossibilidades reais. Por conseguinte, apenas em uma sociedade fundada sobre um processo permanente de abstração.

Em outras palavras, é este movimento primitivo de abstração enquanto núcleo da alienação - que autorizaria o processo de ultrassubjetivação, criando, desse modo, condições propícias à internalização das estruturas sociais autocoercitivas que permeiam a vida contemporânea. Por isso, o próprio Han deve admitir que o movimento do sujeito de desempenho culmina em uma liberdade "paradoxal". O paradoxo dessa liberdade é justamente aquilo que permite sustentar que o conceito marxiano de alienação ainda é operante para a compreensão dos meandros da subjetividade contemporânea: a apreensão de que essa sociedade se sustenta em processos de abstrações reais, dos quais o mais elementar é aquele que põe o trabalho abstrato como determinante da produção de riqueza objetiva - isto é, que consagra a alienação enquanto fenômeno estruturante da totalidade de uma sociedade na qual impera o modo capitalista de produção.

Descrever a forma como esses indivíduos vivenciam existencialmente esse cenário - fazer o que foi chamado de uma "fenomenologia da vida alienada" - , sobretudo à luz das patologias dele advindas, é a tarefa à qual, no futuro, pretendemos nos concentrar.

30 Isto é, não-mecanicista. A ideia de prisma aqui é utilizada no intuito de ilustrar os múltiplos raios diretivos nos quais uma mesma incidência externa (uma determinação) pode se decompor.

${ }^{31}$ Nesse sentido, outra fonte de pesquisa importante diz respeito à forma pela qual o discurso neoliberal é propagado, adequando-se às posições e às perspectivas das classes sociais, cada vez mais fragmentárias, que compõem a sociedade contemporânea. 


\section{Referências bibliográficas}

AGAMBEN, Giorgio. O que é um dispositivo? Trad. Nilceia Valdati. Outra Travessia, n. 5, pp. 9-16, 2005.

DARDOT, Pierre; LAVAL, Christian. La nouvelle raison du monde - essai sur la société néolibérale. Paris: Éditions La Découverte, 2009.

EHRENBERG, Alain. O culto da performance. Trad. Pedro F. Bendassolli. São Paulo: Ideias \& Letras, 2010.

FAUSTO, Ruy. Sentido da dialética - Marx: lógica e política t. I. Petrópolis: Vozes, 2015.

FISCHBACH, Franck. Sans objet - capitalisme, subjectivité, aliénation. Paris: Librairie PhilosophiqueJ . Vrin, 2009.

. "L'aliénation comme réification". In: BAROT, Emmanuel (Dir.). Sartre et le marxisme. Paris: La Dispute, 2011, pp. 285-312.

HAN, Byung-Chul. Sociedade do cansaço. 2. ed. ampl. Trad. Enio Paulo Giachini. Petrópolis: Vozes, 2017.

HARVEY, David. Condição pós-moderna. 17. ed. Trad. Adail Ubirajara Sobral e Maria Stela Gonçalves. São Paulo: Edições Loyola, 2008.

MARX, Karl. O capital - crítica da economia política l. I v. I. Trad. Regis Barbosa e Flávio R. Kothe. 3. ed. São Paulo: Ed. Nova Cultural, 1988.

. O capital - crítica da economia política l. I v. II. Trad. Regis Barbosa e Flávio R. Kothe. Coord. e rev. Paul Singer. São Paulo: Ed. Nova Cultural, 1996.

. Para a crítica da economia política. Trad. Edgard Malagodi. São Paulo: Ed. Nova Cultural, 1999.

. Capítulo VI inédito de O capital - resultados do processo de produção imediata. 2. ed. São Paulo: Centauro, 2004a.

. Manuscritos econômico-filosóficos. Trad. Jesus Ranieri. São Paulo: Boitempo Editorial, 2004b.

. "O 18 Brumário de Luís Bonaparte". In: A revolução antes da revolução v. II. 2. ed. Trad. Álvaro Pina et al. São Paulo: Editora Expressão Popular, 2009.

. Grundrisse. Trad. Mário Duayer e Nélio Schneider. São Paulo: Boitempo, 2011.

MARX, Karl; ENGELS, Friedrich. A ideologia alemã. 8. ed. Trad. J osé Carlos Bruni e Marco Aurélio Nogueira. São Paulo: Editora Hucitec, 1991. 
. Collected works v. 42 - letters 1864-68. Trad. Christopher Upward eJ ohn Peet. Londres: Lawrence \&Wishart, 2010.

MÉSZÁROS, István. A teoria da alienação em Marx. Trad. Isa Tavares. São Paulo: Boitempo, 2010.

SÈVE, Lucien. Aliénation et émancipation - précédé de Urgence de communisme et suivi de Karl Marx: 82 textes du Capital sur l'aliénation. Paris: La Dispute, 2012.

ZIZEK, Slavoj. The interpassive subject. Disponível em: <http:// www.lacan.com/ interpassf.htm>, acessado em 13 ago. 2018.

Como citar:

SANTOS, Vinícius. Trabalho abstrato, subjetividade e alienação em Marx: notas para uma "fenomenologia da vida alienada" a partir de O capital. Verinotio - Revista on-line de Filosofia e Ciências Humanas, Rio das Ostras, v. 24, n. 2, pp. 18-45, nov. 2018.

Data de envio: 20 dez. 2017

Data de aceite: 30 maio 2018 